\title{
Pengaruh Brand Image E-Commerce Terhadap Minat Beli Konsumen (Survei Pada Pelanggan Tokopedia)
}

\author{
Valensia Alvionita Wijaya, Roswita Oktavianti \\ valensia.alvionita@yahoo.com,roswitao@fikom.untar.ac.id \\ Fakultas Ilmu Komunikasi Universitas Tarumanagara
}

\begin{abstract}
Technologyprogress is followed by online media. Nowadays, onlinemedia is not only for searching information but also for business platform (e-commerce). Tokopedia is one of the famous e-commerce known by society. Research with title of "Brand image influence of ecommerce Tokopedia towards consumer buying interest", take possession of outline of the problem whether any brand image influence of e-commerce Tokopedia towards consumer buying interest. This research goal is to understand whether any brand image influence of ecommerce Tokopedia towards consumer buying interest. Concepts used in this research are brand image concept and also interest in buying concept. This research used quantitative research method with collecting 100 samples from respondent. From this research obtained result linear regression I.e. $Y=1,837+0,754 X$ and level of significantly 0,000 which mean there is significance influence between brand image of e-commerce Tokopedia towards consumer buying interest.Brand image influence of e-commerce Tokopedia towards consumer buying interest stated immensely strong, proofed by correlation coefficient in the amount of 0,836 .
\end{abstract}

Keyword:E-commerce, Brand Image, Buying Interest

\begin{abstract}
Abstrak
Majunya perkembangan teknologi juga diikuti dengan majunya media online. Kini media online tidak hanya digunakan untuk mencari informasi saja, melainkan merupakan suatu lapak bisnis (e-commerce). Salah satu e-commerce yang dikenali oleh masyarakat yaitu Tokopedia. Penelitian dengan judul "Pengaruh Brand Image E-commerce Tokopedia terhadap Minat Beli Konsumen", memiliki rumusan masalah apakah terdapat Pengaruh Brand Image e-commerce Tokopedia terhadap Minat Beli Konsumen. Penelitian ini memiliki tujuan yaitu untuk mengetahui apakah terdapat pengaruh brand image e-commerce Tokopedia terhadap Minat Beli Konsumen. Konsep yang digunakan pada penelitian ini adalah konsep brand image dan juga konsep minat beli. Pendekatan penelitian yang digunakan pada penelitian ini adalah pendekatan kuantitatif dengan jumlah sampel sebanyak 100 responden. Dari penelitian diperoleh hasil regresi linear yaitu $Y=1,827+0,754 \mathrm{X}$ dan tingkat signifikasi 0,000 yang berarti menyatakan adanya pengaruh yang signifikan antara brand image e-commerce Tokopedia terhadap minat beli konsumen. Pengaruh brand image e-commerce Tokopedia Terhadap Minat Beli Konsumen dikatakan sangat kuat, dibuktikan oleh uji koefisien korelasi sebesar 0,836
\end{abstract}

Kata kunci : E-commerce, Brand Image, Minat Beli

\section{Pendahuluan}

Semakin majunya teknologi serta arus informasi membuat masyarakat Indonesia semakin terbuka dalam pengetahuan secara global. Perkembangan teknologi memudahkan masyarakat untuk melakukan segala aktivitas. Semakin 
majunya perkembangan teknologi juga di ikuti dengan perkembangan media baik media online maupun media elektronik. Kini media online tidak hanya digunakan untuk mencari informasi saja, melainkan media online juga sudah menjadi lahan bisnis atau kini sering disebut dengan bisnis online (e-commerce). E-commerce adalah penjualan barang serta jasa secara langsung (direct selling) yang dilakukan melalui internet (dalam Morissan, 2015). Dalam hal ini, salah satu platform ecommerce Indonesia yang aktif adalah Tokopedia. Tokopedia merupakan salah satu tempat berbelanja online di Indonesia yang memungkinkan untuk individu, toko kecil, maupun brand untuk melakukan transaksi jual-beli atau transaksi secara online. Brand Image yang dimiliki oleh Tokopedia yang sudah dikenali masyarakat Indonesia memiliki beberapa kelebihan di bandingkan platform e-commerce lainnya. Menurut Keller, citra merek diartikan sebagai suatu persepsi mengenai merek yang merefleksikan memori konsumen padaasosiasinyaterhadap suatu merek (dalam Dewi, 2008).

Konsep dalam penelitian ini adalah brand image dan minat beli. Citra merek atau brand image adalah kumpulan suatu asosiasi mengenai merek yang melekat dan juga terbentuk pada benak pelanggan. Maka dapat disimpulkan bahwa citra merek atau brand image diartikan sebagai sekumpulan asosiasi yang dipersepsikan oleh pelanggan terhadap suatu merek/brand dan dapat disampaikan melalui sarana komunikasi yang ada (dalam Winduwati, 2016).Menurut Keller (dalam Ginting, 2017) terdapat beberapa dimensi brand image yaitu sebagai berikut:

\section{Strength of Brand Associations}

Suatu citra merek dapat dibentuk melalui kekuatan asosiasi merek yang kuat. Kekuatan pada asosiasi merektersebut dipengaruhi pada bagaimana informasi tersebut masuk ke dalam pikiran pelanggan dan bagaimana informasi tersebut mampu dipertahankan sebagai bagian dari suatu merek tertentu. Keunggulan dari asosiasi merek merupakan salah satu pembentuk citra merek, dimana produk tersebut mempunyai keunggulan atau kekuatan. Sumber informasi dalam membentuk brand image memiliki kekuatan atau dimensi yaitu atribut merek dan manfaat merek.

\section{Favorability of Brand Associations}

Bagaimana merek tersebut dapat memberikan suatu keyakinan bagi konsumennya dan juga menjadi salah satu pertimbangan konsumen dalam terciptanya brand image tersebut di benak konsumen. Brand harus dapat memberikan pemasaran yang sesuai dan janji-janji yang terpenuhi dalam upaya memenuhi kebutuhan konsumen yang belum terpuaskan. Dengan demikian, brand dianggap memiliki kapabilitas dan meyakinkan dalam memenuhi kebutuhan konsumen.

\section{Uniqueness of Brand Associations}

Keunggulan dan keunikan memiliki pengaruh yang sangat penting agar dapat bersaing dengan merek lainnya dan dapat dijadikan sebagai suatu pertimbangan konsumen untuk memilih merek tersebut. Keunikan dari suatu brand akan menjadi faktor yang membedakan suatu brand dengan brand pesaingnya.

Konsep kedua adalah minat beli Menurut Engel. Minat beli adalah suatu kekuatan yang mendorong dan motif untuk mendorong seseorang menaruh perhatian secara spontan, mudah, tanpa paksaan dan selektif pada suatu produk dan kemudian mengambil keputusan membeli (dalam Ningrum, 2016). Indikator minat beli terdiri dari yaitu (dalam Ferdinand, (2002) : 
Valensia Alvionita Wijaya, Roswita Oktavianti: Pengaruh Brand Image E-Commerce terhadap Minat Beli Konsumen (Survei Pada Pelanggan Tokopedia)

\section{Minat transaksional}

Minat seseorang untuk membeli produk. Hal ini berarti konsumen memiliki minat untuk membeli suatu produk atau barang teretntu yang diinginkan oleh pelanggan dalam memenuhi kebutuhannya.

2. Minat referensial

Keinginan individu untuk mereferensikan produk kepada orang-orang terdekatnya. Dengan demikian, konsumen yang telah memiliki minat untuk melakukan pembelian, akan menyarankan orang-orang terdekat atau yang berada di sekitarnya untuk melakukan pembelian pada produk yang sama atau serupa.

\section{Minat preferensial}

Perilaku yang digambarkan melalui prefrensi seseorang pada produk tertentu. Preferensi ini dapat diubah apabila terjadi suatu halyang berkaitan dengan produk prefrensi atau yang disukainya.

4. Minat eksploratif

Minat ini menunjukkan adanya perilaku yang ingin atau berusaha mencari informasi mengenai suatu produk yang diminati dan mencari informasi yang dapat mendorong untuk melakukan kegiatan pembelian.

Berdasarkan latar belakang tersebut, maka penuli tertarik untuk meneliti "Pengaruh Brand Image E-commerce terhadap Minat Beli Konsumen (Survei Pada Pelanggan Tokopedia). Penelitian ini memiliki tujuan yaitu untuk mengetahui apakah terdapat pengaruh brand image e-commerce Tokopedia terhadap minat beli konsumen.

\section{Metode Penelitian}

Pendekatan penelitian yang digunakan penulis adalah pendekatan kuantitatif. Penelitian kuantitatif diartikan sebagai metode penelitian yang berlandaskan pada filsafat positivism, tujuan penelitiannya adalah untuk meneliti populasi dan sampel, teknik pengambilan sampel yang pada umumnya dilakukan dengan cara random, dan analisis data yang bersifat kuantitatif bertujuan untuk menguji hipotesis yang telah ditetapkan ( dalam Sugiyono, 2012:14).Dalam penelitian ini, metode penelitian yang digunakan oleh penulis adalah metode survei eksplanatif asosiatif. Survei bersifat eksplanatif asosiatif yang berarti menjelaskan hubungan (korelasi) antar variabel (dalam Kriyantono, 2006:362).

Populasi diartikan sebagai suatu wilayah yang terdiri dari subjek atau objek yang mempunyai kualitas serta karakteristik dan kemudian ditentukan oleh peneliti untuk dipelajari dan kemudian diambil kesimpulannya (dalam Sugiyono, 2012 : 119). Populasi dari penelitian ini adalah seluruh pengguna e-commerce Tokopedia. Sampel diartikan sebagai suatu bagian dari jumlah serta karakteristik yang dimiliki oleh populasi (dalam Sugiyono, 2017:62).Menurut Roscoe, minimal sampel sebanyak 30 sampai dengan 500 subjek dan hal ini didasarkan pada perhitungandalam statistik (Sugiyono, 2012:91). Dalam penelitian ini, penulis menetapkan jumlah sampel sebanyak 100 responden, dengan kriteria sampel bahwa responden adalah individu yang pernah berbelanja di e-commerce Tokopedia.

Teknik yang digunakan untuk pengambilan sampel yaitu teknik sampling non probabilitas. Penulis menggunakan teknik sampling yang berjenis accidental sampling yang dimana periset memilih siapa saja yang kebetulan dijumpai untuk dijadikan sampel. (dalam Kriyantono 2006:160). 
Penelitian ini menggunakan metode pengumpulan data yaitu pertama, kuisioner yang merupakan teknik untuk mengumpulkan informasi yang memungkinkan untuk menganalisis sikap, perilaku, yang bisa terpengaruh oleh suatu sistem yang telah ditentukan (dalam Syofian, 2013:44). Kedua, studi kepustakaan dilakukan dengan cara mencari data atau informasi penelitian melalui jurnal ilmiah, buku-buku , dan bahan-bahan publikasi. Ketiga, Skala pengukuran merupakan upaya memberikan suatu tanda berupa bilangan pada suatu peristiwa maupun pada objek dengan aturan-aturan tertentu (dalam Kriyantono, 2006:135). Pada penelitian ini, skala pengukuran yang digunakan pada penelitian ini adalah skala Likert.

Dalam penelitian ini digunakan teknik analisis data yang berupa uji t, uji koefisien korelasi, uji koefisien determinasi, dan analisis regresi sederhana.Sedangkan, teknik keabsahan data yang digunakan pada penelitian ini yaitu uji validitas, reliabilitas dan normalitas.

\section{Hasil Temuan dan Diskusi}

Uji Validitas

Tabel 1 Variabel X (Brand image)

\begin{tabular}{rrr}
\hline No. Butir & r hitung & r tabel \\
\hline T1 & .614 & .909 \\
T2 & .717 & .904 \\
T3 & .661 & .907 \\
T4 & .741 & .903 \\
T5 & .718 & .904 \\
T6 & .720 & .904 \\
T7 & .750 & .903 \\
T8 & .509 & .915 \\
T9 & .639 & .908 \\
T10 & .639 & .909 \\
T11 & .673 & .907 \\
\hline
\end{tabular}

Berdasarkan tabel 1, sebanyak sebelas butir pernyataan dalam variabel (X1) "Brand Image" memiliki nilai $\mathrm{r}$ hitung $>0,200$, yang berarti semua pernyataan pada X1 telah valid.

Tabel 2 Variabel Y (Minat Beli)

\begin{tabular}{ccc}
\hline No. Butir & r hitung & r tabel \\
\hline T12 & .642 & .901 \\
T13 & .717 & .896 \\
T14 & .711 & .897 \\
T15 & .777 & .893 \\
T16 & .649 & .902 \\
T17 & .707 & .899 \\
T18 & .661 & .900 \\
T19 & .744 & .895 \\
T20 & .672 & .900 \\
\hline
\end{tabular}

Berdasarkan tabel 2, sebanyak sembilan butir pernyataan dalam variabel (Y1) "Minat Beli" memiliki nilai $r$ hitung $>0,200$, yang berarti semua pernyataan pada Y1 telah valid. 
Valensia Alvionita Wijaya, Roswita Oktavianti: Pengaruh Brand Image E-Commerce terhadap Minat Beli Konsumen (Survei Pada Pelanggan Tokopedia)

Uji Normalitas

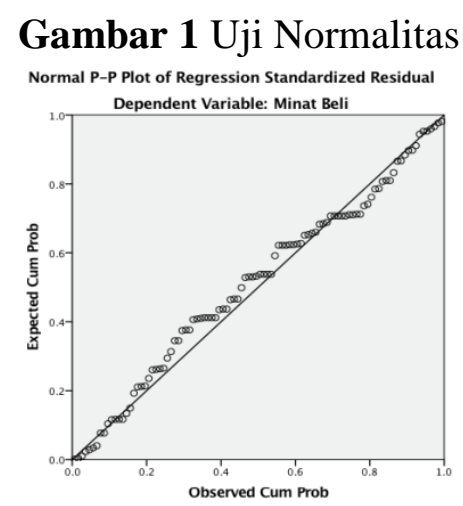

Berdasarkan Gambar 1, disimpulkan bahwa data dikatakan menyebar di sekitar garis diagonal dan mengikuti arah garis diagonalnya, maka dapat disimpulkan bahwa data yang digunakan merupakan data yang terdistribusi secara normal.

Uji Reliabilitas

Tabel 3 Variabel X (Brand Image)

\begin{tabular}{cc}
\hline Cronbach's Alpha & N of Items \\
\hline 0,915 & 11 \\
\hline
\end{tabular}

Dari pengujian reliabilitas dengan menggunakan program SPSS terdapat 11 butir variabel Brand Image, di dapat nilai Cronbach's Alpha sebesar 0,915 yang berarti butir-butir Brand Image tersebut dikatakan reliabel karena memiliki nilai Cronbach's Alpha $>0,6$.

Tabel 4 Variabel Y (Minat Beli)

\begin{tabular}{cc}
\hline Cronbach's Alpha & N of Items \\
\hline 0,908 & 9 \\
\hline
\end{tabular}

Dari pengujian reliabilitas dengan menggunakan program SPSS terdapat 9 butir variabel Minat Beli, di dapat nilai Cronbach's Alpha sebesar 0,908 yang berarti butir-butir Minat Beli tersebut dikatakan reliabel karena memiliki nilai Cronbach's Alpha $>0,6$

Uji Koefisien Korelasi dan determinasi

Tabel 5 Koefisien Korelasi dan Determinasi

\begin{tabular}{|r|r|r|r|}
\hline Model & R & R Square & $\begin{array}{c}\text { Adjusted R } \\
\text { Square }\end{array}$ \\
\hline 1 & $.836^{\mathrm{a}}$ & 0,699 & 0,696 \\
\hline
\end{tabular}


Dari hasil perhitungan tabel 5, nilai koefisien korelasi (r) sebesar 0,836 yang artinya hubungan antara brand image dan minat beli mempunyai pengaruh yang sangat kuat. Nilai koefeisien korelasi dikatakan sangat kuat karena berada pada rentang 0,800 1,000.Sedangkan nilai koefisien determinasi pada tabel $\mathrm{R}$ square sebesar 0,699 menunjukkan bahwa 69,9\% Minat Beli konsumen dipengaruhi oleh brand image, sementara sisanya 30,1\% dipengaruhi oleh variabel-variabel lain.

Uji T dan Analisis Regresi sederhana

Tabel 6 Uji T dan Analisis Regresi Sederhana

\begin{tabular}{|c|c|c|c|c|c|c|}
\hline & \multirow[t]{2}{*}{ Model } & \multicolumn{2}{|c|}{$\begin{array}{l}\text { Unstandardized } \\
\text { Coefficients }\end{array}$} & \multicolumn{3}{|l|}{$\begin{array}{l}\text { Standardized } \\
\text { Coefficients }\end{array}$} \\
\hline & & $\mathrm{B}$ & $\begin{array}{l}\text { Std. } \\
\text { Error }\end{array}$ & Beta & $\mathrm{T}$ & Sig. \\
\hline \multirow[t]{2}{*}{1} & (Constant) & 1.827 & 2.278 & & .802 & .425 \\
\hline & $\begin{array}{l}\text { Brand } \\
\text { Image }\end{array}$ & .754 & .050 & .836 & 15.083 & .000 \\
\hline
\end{tabular}

Berdasarkan table 6, nilai t sebesar $=15,083$ dan tingkat signifikasi $=0,000<0,05$. Karena nilai $\mathrm{p}<0,05$ maka dapat dinyatakan bahwa Ho di tolak dan Ha diterima, yang berarti terdapat pengaruh brand image terhadap minat beli konsumen di Tokopedia. Terdapat pengaruh yang signifikan antara brand image terhadap minat beli karena tingkat signifikasi lebih kecil dari 0,05. Pengaruh ini tidak hanya berpengaruh kepada sampel saja tetapi juga pada populasi. Pengaruh tersebut positif sehigga semakin tinggi brand image Tokopedia maka semakin tinggi minat beli konsumen, sebaliknya semakin rendah brand image Tokopedia maka semakin rendah pula minat beli konsumennya.

Berdasarkan tabel 6 , diketahui bahwa nilai parameter dari regresi linear sederhana dengan hubungan $\mathrm{X}$ mempengaruhi $\mathrm{Y}$ adalah:

$\mathrm{a}=1,827$

$\mathrm{b}=0,754$

Dengan demikian didapatkan nilai regresi linear sederhana sebesar

$\mathbf{Y}=\mathbf{1 , 8 2 7}+\mathbf{0 , 7 5 4 X}$

Berdasarkan persamaan diatas, maka dapat diartikan bahwa nilai sebesar 1,827 menyatakan sebagai konstanta dari fungsi regresi yang menunjukkan bahwa apabila tidak ada kenaikan pada variabel $\mathrm{X}$, maka pada variabel $\mathrm{Y}$ akan mencapai 1,827. Setiap ada penambahan angka atau perubahan pada variabel $\mathrm{X}$ (brand image), maka variabel Y (minat beli) akan mengalami peningkatan sebesar 0,754.

\section{Simpulan}

Dalam penelitian ini, terdapat pengaruh yang sangat kuat antara brand image ecommerce Tokopedia terhadap minat beli konsumen. Dibuktikan oleh koefisien korelasi sebesar 0,836. Berdasarkan hasil uji koefisien determinasi, di dapati bahwa pengaruh brand image e-commerce Tokopedia terhadap minat beli konsumen dinyatakan memiliki pengaruh yaitu sebesar $69,9 \%$ dan sisanya 30,1\% dipengaruhi oleh faktor lain. Terdapat pengaruh yang signifikan antara brand image terhadap minat beli karena tingkat signifikasi lebih kecil dari 0,05 . Pengaruh ini tidak hanya 
berpengaruh kepada sampel saja tetapi juga pada populasi. Pengaruh tersebut positif sehigga semakin tinggi brand image Tokopedia maka semakin tinggi minat beli konsumen, sebaliknya semakin rendah brand image Tokopedia maka semakin rendah pula minat beli konsumennya. Dari penelitian ini ditemukan persamaan regresi linear sederhananya yaitu $\mathrm{Y}=1,827+0,754 \mathrm{X}$. Selain itu berdasarkan hasil uji $\mathrm{T}$ didapati bahwa Ho ditolak dan Ha diterima yang berarti terdapat pengaruh yang signifikan antara variabel brand image e-commerce Tokopedia terhadap minat beli konsumen.

\section{Ucapan Terima Kasih}

Ucapan terimakasih diberikan penulis kepada seluruh responden atas kesediaan dan kerjasamanya selama penelitian berlangsung.

\section{Daftar Pustaka}

Ferdinand, A. (2002). Pengembangan Minat Beli Ekstensi. Semarang: Badan Penerbit Universitas Diponegoro.

Ferrinadewi. (2008). Merek \& Psikologi Konsumen. Yogyakarta: Graha Ilmu.

Ginting, I. (2017). Pengaruh Citra Merek (Brand Image) Terhadap Keputusan Pembelian Konsumen (Studi Pada Maskapai Penerbangan Air Asia sebagai Low Cost Carrier. Jurnal Mahasiswa Manajemen Universitas Tanjungpura, $6(2): 1-14$.

Kriyantono, Rachmat. (2006). Teknik Praktis Riset Komunikasi. Jakarta: PT. Kencana Perdana.

Lusia, S. S. U, Yugih, S., \& Septia, W.(2016). Strategic Public Relations In Building Brand Image Eco-Tourism Lombok. E-Proceeding Comicos Published by Faculty of Social and Political Sciences Universitas Atma Jaya Yogyakarta

Morissan. (2015). Periklanan: Komunikasi Pemasaran Terpadu Edisi Pertama. Jakarta: Prenadamedia Group.

Ningrum, I. T. (2016). Pengaruh Event Dan Brand Image Terhadap Minat Beli Produk Rokok Sampoerna A Mild Pada Pt. Hm Sampoerna Area Marketing Surabaya. Jurnal Manajemen Kinerja Universitas Narotama Surabaya, 2(1):57-69.

Rangkuti, F. (2004). The Power of Brand. Jakarta: PT. Gramedia Pustaka Utama.

Siregar, S. (2013). Metode Penelitian Kuantitatif. Jakarta: PT. Fajar Interpratama Mandiri.

Sugiyono. (2012). Metode Penelitian Kuantitatif, Kualitatif dan R\&D. Bandung: Alfabeta.

Sugiyono. (2017). Metode Penelitian Kuantitatif, Kualitatif dan R\&D. Bandung: Alfabeta. 